\title{
TRAUMATIZATION OF THE PAST AND MARTYROLOGICAL THINKING IN THE SOVIET UNION AND THE POST-SOVIET SPACE
}

\author{
Daniil Anikin \\ Associate Professor of History and Theory of Policy \\ Moscow State University, Russia \\ Researcher \\ Tomsk State University, Russia \\ dandee@list.ru
}

\begin{abstract}
The purpose of the article is to analyze the mechanisms of the transformation of martyrological thinking in the Soviet Union and in post-Soviet Russia. The methodological basis of the study is constituted by the works written by the representatives of functionalism (E. Durkheim, M. Halbwachs, P. Bourdieu, J.C. Alexander), who raise the issue of the important role of religious rituals and forms of thinking in social space. Martyrological thinking creates martyrdom cults, performing an ambivalent function. On the one hand, this thinking is a way to maintain a collective identity, and on the other, a way to damage and destroy it. The author concludes that in Soviet society two main stages that formed martyrdom cults can be distinguished: the periods of the Civil War and the Great Patriotic War. In both cases, martyrological thinking was an important factor in the consolidation of the society. In post-Soviet society, martyrological thinking becomes a factor that causes the deconstruction of the symbolic space and a hidden factor in the destabilization of the political organization. The perception of the conservative part of the Russian society is expressed in the formation of the cult of the last Russian emperor, Nicholas II, which, on the one hand, allows to mitigate the historical responsibility, and on the other becomes a moral justification for criticizing the continuity of modern Russian power in relation to the Soviet Union.
\end{abstract}

Keywords: civil religion, identity, martyrological thinking, martyrs, memory studies, post-Soviet space, sacralization, Soviet Union, traumatization

\section{INTRODUCTION}

On July 3, 2020, a Russian monk called Sergius (Romanov), who had gained wide public fame in the past months, was deprived of his rank, which was primarily due to his criticism of sanitary measures aimed to prevent the 
COVID-19 pandemic. The criticism of church hierarchs who agreed to close churches in order to reduce the risk of the spread of the disease coincided with the dissatisfaction of a significant part of the faithful, which gave his statement a distinct political meaning. But long before that, Sergius had become one of the leaders of the Tsar-as-God movement, proclaiming that the martyrdom of Emperor Nicholas II is a kind of atonement for Russia for all the sins of its population. A certain ambiguity of this position was also expressed by the secular surname Sergius (Romanov), which coincided with the most common version of the surname of the Russian imperial family.

From a canonical point of view, this ideological position does not withstand any criticism; nevertheless, it has become quite popular among ordinary parishioners and the political and cultural establishment. The popularity of this position raises the question of the role martyrdom plays in the Soviet and post-Soviet mass consciousness, and the reason why such attention is paid to the very phenomenon of martyrdom and also the importance of martyrdom in the context of the design of a collective trauma.

The tragic twentieth century became a difficult test for the entire former Russian Empire, and then for the Soviet Union, awakened several trends in the public consciousness of the Russian society, which demonstrated a kind of distortion of cultural stereotypes in the new social and political conditions. The reluctance to accept a collapse of values related to the prospects for the state development and its place in these processes has led to the emergence of moral resentment.

This phenomenon clearly manifested itself in the emergence and cultivation of the image of the enemy that gave rise to a real persecution mania in both Soviet and post-Soviet societies. The difference was only in the kind of image the enemy took on a case-by-case basis in order to inflict an unexpected blow. In various time periods, it assumed the image of a foreign interventionist or a wealthy peasant hiding grain and condemning the fellow citizens to starvation, or of a fascist who had bitten on the Russian soil. In the post-Soviet period, especially in the 2000 s, new figures of liberals were added to the bizarre echoes of the images remaining in historical memory, seeking to subjugate the Russian civilization to the West not by violence, but by discrediting and humiliating its values. However, where the image of the enemy arises, there is also the opposite image, which is usually the hero. But in the case of a traumatized society, painfully experiencing its disadvantage and inferiority, the hero appears in a kind of hypostasis of the victim, a martyr who is not able to defeat himself, but who is able to take a blow with his tragic death and, thereby, ensure the overcoming of catastrophic circumstances. 
Collective trauma is thus expressed as an individual victim who takes a specific position. On the one hand, such a sacrifice should be a part of the community, and on the other hand, it should have individual features that allow us to create a background to the sacrificial feat, to demonstrate that the divine choice was arbitrary rather than random. According to R. Girard, the general logic of a sacrifice is that the obligatory elements are not only the victim and the one who makes the sacrifice, but also the community that is not ready to fully identify with this victim (Girard 1977: 11). The martyr must be close enough to the community for the latter to be able to consolidate around their memory, but they must also be removed far enough from it not to create constant fear that each representative of the community could also become a victim. The phenomenon of martyrdom is based not on the very fact of excruciating death, but on the readiness of public consciousness for its religious perception, and as a result - for the sacralization of the dead as martyrs. In this sense, the study of martyrs is not as much a subject of history or religion but as of sociology and political science, because the key question is not to establish the true causes of death, but to identify the subsequent social effect.

It should be stated in advance that the prospect of such a question is a comprehensive study of the relationship between the images of martyrs and collective injuries in Eastern Europe in the context of the concept of two occupations. However, the format of the journal article forces me to turn to the analysis of a specific aspect, namely, the cultural origins of martyrological thinking in Russia, its special manifestation in the Soviet Union and in the post-Soviet space.

\section{RESEARCH METHODOLOGY}

The tasks dictate access to a wide range of sources, since the identified problem is located at the intersection of several areas of humanitarian knowledge. Firstly, there is an essential appeal to the functionalist approach, represented by E. Durkheim, M. Halbwachs, P. Bourdieu, and J. Alexander. E. Durkheim in his work The Elementary Forms of Religious Life first actualized the question of the inextricable connection of religious cults and social needs, in particular the desire to form and maintain the collective identity (Durkheim 1995 [1912]: 5-7). M. Halbwachs became the founder of memory studies, outlining the leading role of collective memories in ensuring the identity of individual communities, as well as paying special attention to the specifics of religious communities as subjects of memory policy. In his later book, La Topographie légendaire des Évangiles en Terre Sainte; étude de mémoire collective, he analyzed the process 
of constructing the collective memory about Christian shrines (Halbwachs 1941). His important conclusion was the explanation of the important role of religious collective memory due to its appealing to the transcendental order, while historical facts became only representations of timeless divine reality.

P. Bourdieu synthesized functionalist and phenomenological approaches and formulated the principle of the double structuring of reality. According to this principle, it was utopian to represent a society as a system of collective ideas or a combination of social and political institutions. In fact, there was an inextricable relationship between the subjective and objective aspects of the formation of social structures, between which there was a constant symbolic exchange. The concept of the symbolic exchange, which allowed us to include the achievements of anthropologists in the discourse of social sciences, indicated the key role of the symbolic capital of a social institution in the process of maintaining or transforming social reality (Bourdieu 1986). Symbolic capital did not have any material characteristics, but this did not prevent it from 'flowing' from one social subject to another, having the logic of accumulation and waste.

To understand the connection of symbolic capital and trauma, the work of J. Alexander is of great importance. His theoretical position is related to the methodological renewal of the functionalist approach, which allows us to overcome the remnants of positivism and propose a new program for the analysis of social phenomena (Alexander 2004a: 527-573). In particular, the specifics of collective injuries are considered by J. Alexander not in terms of strengthening their quantitative indicators (the number of people who consider themselves injured), but in the framework of changing cultural codes that create more effective mechanisms of a collective trauma. On the example of the Holocaust, he shows how the concept of collective trauma depends on the process of medialization, and the role of victims is determined not by the very nature of the crimes committed but by the emerging cultural effect (Alexander 2004b: 1-30).

Over the past few years, a number of publications have appeared that draw attention to the individualization of collective trauma in the images of specific victims - real or invented. The psychological aspect of this problem is shown in the work of J. Bélanger (2014). Important comments about the social aspects of the martyrdom phenomenon, as well as about the ratio of martyrs, heroes, and victims have been made by O. Gölz (2019: 27-38).

In a special issue of the Journal of Soviet and Post-Soviet Politics and Society in 2015, a number of articles were published which analyzed the use of the image of martyrs as a means of legitimizing or destroying the political order. A particular emphasis was placed on the study of Eastern Europe in the context of overcoming the consequences of socialist regimes, memory borrowing, and the Holocaust. Particular attention should be paid to an article by U. Blacker, 
in which he demonstrates how the creation of the image of a martyr becomes a performative act that can destroy the symbolic order and trigger a reaction of debunking the legitimacy of the political elite (Blacker 2015: 257-260). In a recent book, U. Blacker addresses in more detail the methods of forming martyrological thinking in Eastern Europe, turning victims into martyrs in the context of overcoming the communist heritage and strengthening national identity (Blacker 2019).

\section{MARTYRDOM AS A HISTORICAL AND SOCIAL PHENOMENON}

To begin with, it is necessary to understand the concept of martyrdom in its early Christian meaning, as well as in the medieval culture of Western and Eastern Europe. The first martyrdom of Christians was recorded in the 1st century, only a few years after the events described in the Gospel. But the question is, when these deaths started to be regarded as the martyrdom. It is necessary to distinguish the very fact of martyrdom and its perception as martyrdom. In other words, it is not immediately clear in the early Christian communities that the death of martyrs was an evidence of their faith, and therefore the memory of them was a decisive element in the preservation and maintenance of the collective identity of these communities. S. Price believes that in the eastern provinces of the Roman Empire, the formation of a kind of martyrological thinking was facilitated by the existence of numerous pagan cults associated with compulsory sacrifices (Price 1984: 118).

The high symbolic status of martyrs led to some competition between Christian communities for the discovery and appropriation of early Christian martyrs, and the need for appropriate argumentation caused the emergence of a new genre of religious literature - Acts of the Martyrs. These are biographies of saints, which were periodically added for convincing apocryphal protocols of interrogations, which were supposed to demonstrate perseverance in faith (Frend 2008 [1965]). Martyrdom had a certain mimetic meaning, since it likened the martyr to Jesus himself, but still death was more important as an act of evidence of the truth of the Christian tradition.

It can be stated that for Christian consciousness the metaphysical significance of what happened is not the very fact of martyrdom. Martyr in its original meaning is not so much a victim but rather a witness. Martyrdom gives evidence of the strength of the human spirit and Christian faith over negative circumstances, and in this case it marks the victory of Christ over his opponents.

For ordinary consciousness, the differences between victims and martyrs are insignificant, but in fact their only important property is the lack of guilt. 
In other words, victims and martyrs are equally not guilty and get the punishment. However, there are still more significant differences. Victims acquire their status only when they are executed, while martyrs choose their life position that implies indifference to earthly existence for the sake of the Christian faith and the posthumous existence of the soul. Another significant difference that stems from this circumstance is the activity of martyrs and the passivity of victims. Activity is shown not in the desire to get ahead of a criminal act or, even more so, to commit a similar crime, but in the conscious desire to defend one's own position, regardless of how this desire is appreciated by others.

It is worth mentioning that martyrdom in itself is considered as a social phenomenon, which is the product of a certain symbolic representation. Therefore, characteristics such as activity or passivity indicate not the actual actions of the historical character, but the perception of their behavior by the community, which marks symbolic space, highlighting those figures that are most clearly able to express collective expectations.

No less important is the degree of personalization. Victims are the embodiment of quantitative losses, so they are not usually called by name (it is enough to recall the famous inscription at the Tomb of the Unknown Soldier in Moscow, "Your name is unknown, your deed is immortal", which is attributed to the author of the Soviet anthem, Sergey Mikhalkov). More precisely, it is the countless names of the victims that give them the necessary anonymity, each victim is no different from all the others, which gives a universal character to the very phenomenon of sacrifice. Unlike countless victims, every martyr is unique, they must have a biography that not only describes the very fact of martyrdom, but also explains why they can be considered as a witness to faith. These differences can be summarized in the following table:

\begin{tabular}{|l|l|l|}
\hline Criterion & Martyr & Victim \\
\hline Foundation of status & Life & Death \\
\hline Basic quality & Activity & Passivity \\
\hline Degree of personalization & Individuality & Anonymity \\
\hline
\end{tabular}

In addition, from a canonical point of view, martyrs and passion bearers should be distinguished. The difference between them is that martyrs are injured for their faith, and passion bearers for the fulfillment of divine commandments (Olivola \& Shafir 2013: 91-92). But these differences, essential from the point of view of church law, are easily overcome in the minds of those social groups for which specific historical figures have become martyrs not only because of theological definitions, but because of the significance of their tragic demise for the consolidation of a certain community. Martyrdom in European history 
quickly becomes a massive phenomenon, and the discrepancy between the official procedures for identifying saints and the local cults of martyrs becomes quite significant. As a rule, this state of affairs caused dissatisfaction with the church authorities, but it was far from possible to always cope with the peculiarities of mass consciousness. Therefore, a significant part of the martyr cults was eventually recognized by the church and included in the official practice of remembrance.

In this sense, the whole Russian history, permeated by the religious perception of time, is closely connected with the aggravated attention to martyrs - not only for faith, but also for the truth. The first Russian saints (passion bearers) are brothers Boris and Gleb, who died, according to the annals, at the hands of their own brother. But their martyrdom not only demonstrates the individual feat of preserving the Christian faith, but also becomes a justification for the civilizational choice between Orthodoxy and paganism. The figures of the dead brothers turned into a symbol of Christian sacrifice, but also gave rise to the cult of their veneration as the founders of a new cultural community. It is very important that, as a rule, in the Russian Orthodox tradition representatives of the royal family became passion bearers, which was an additional factor in combining dynastic and religious ties. This led to a kind of symbolic competition between the most noble clans in medieval Russia for identifying their ancestors as saints, or for linking their origin with the already famous passion bearers.

The imperial period of Russian history was the time of subordination of the Orthodox Church to the power of a secular ruler. A logical consequence of the decrease in the symbolic significance of religious memory was a certain preservation of the number of martyrs (from a canonical point of view - passion bearers), the maintenance of existing cults, but an unspoken ban on the appearance of new ones. It is significant that the resulting symbolic lacuna began to be filled with political opponents of the government. In the environment of Old Belief there is the cult of the archpriest Avvakum, who was burned by royal servants in 1682, and in the nineteenth century in the environment of the oppositional intellectuals the idea of participants of the Decembrist revolt of 1825 as martyrs (Mazour 1937: 11-14).

\section{SOVIET MARTYRS: BELIEF IN A COMMUNIST FUTURE INSTEAD OF CHRISTIAN ESCHATOLOGY}

The collapse of the imperial system meant not only the liberation of the church from state oppression (for a short period of time it regained autonomy from secular authorities), but also the formation of a new symbolic system. The 
creation of this system was delayed by the prolonged establishment of Soviet power in the territory of the former empire for several years, but it was these years of the Civil War that led to a new surge in martyrological thinking. From a social point of view, the creation of civil cults of martyrs was necessary to legitimize and justify the new political order, which experienced an acute shortage of not only economic but also symbolic resources. As J. Alexander shows, it is the creation of a collective trauma, personified in the images of victims, that becomes an act of establishing a new collective identity (Alexander 2004b: 12-13). An equally important factor is a gap between the community that constructs the injury and the community that results from the injury. In other words, the martyr should be perceived as part of the community, but they should have some features that allow them to focus on their personal fate.

Summing up the Civil War meant both the creation of a periodically replenished or modified list of heroes, and the establishment of cults of martyrs. A large role in distinguishing these categories of symbolically significant characters was played, as expected, by martyrdom during the Civil War or an imminent departure from life, which could be attributed to the consequences of military injuries. As it soon turned out, in the Soviet Union it was better to be a martyr than a hero. At least the period of mass repression of the 30s of the twentieth century significantly reduced the list of heroes, while the cults of the dead participants in the Civil War were able to maintain their significance until the end of the existence of the Soviet state, even despite another wave of designation as martyrs in the Great Patriotic War.

Of course, the ideological content of martyrdom is changing. The moral and metaphysical justification for the tragic death is not Christian faith, but faith in the establishment of communism, and the authors of the new Acts of the Martyrs emphasize the conscious nature of this faith, as well as the willingness to meet death for it. The new martyrs include participants in the Civil War (S. Lazo, V. Bonivur) as well as victims of terrorist acts (M.S. Uritsky, V. Volodarsky). Periodically, foreign allies of the USSR were also included in the pantheon of revolutionary martyrs; for example, the memory of the Italian anarchists F. Sacco and B. Vanzetti, who were shot in 1927, was quickly immortalized in the names of the streets and in the corresponding literature.

The beginning of World War II, catastrophic for the Soviet Union, made it possible and even necessary to mold new martyrdom cults again. The characters of the Civil War had already noticeably faded in the mass consciousness; in addition, an important turn took place in symbolic politics - from the idea of a world revolution, the leadership of the USSR turned to the idea of national history, so the defense of the motherland became the new ideological content of martyrological thinking. The pantheon of martyrs formed in the war years 
remained almost unchanged until the end of the existence of the Soviet Union, which was facilitated by the active consolidation of their images in fiction: B. Polevoi's novel titled A Story About a Real Man, in which the prototype of the hero was pilot A.P. Maresyev; L. Kassil's novel titled The Street of the Younger Son, which described the fate of a young partisan, Volodia Dubinin, etc.

For Soviet martyrs, a deliberate 'reversal' of their social status turned out to be significant. While in the dynastic period the martyr necessarily had to confirm the dominant status of the ruling dynasty, in Soviet society the worker or peasant origin became a mandatory attribute of the martyr. Not a single native of the former classes could claim such an honorary status, and if there were embarrassing circumstances, they were deleted from the official biography. The example of partisan Zoya Kosmodemyanskaya, one of the most prominent representatives of the Soviet pantheon, is indicative of the fact. Despite the characteristic surname, which indicated its origin from the church environment, official documents and fiction consistently emphasized her origin from the lower social strata as well as the low material wealth of the family during her childhood.

\section{“NEW MARTYRS": BETWEEN A POLITICAL ORDER AND MORAL RESENTMENT}

The collapse of the Soviet Union marked a dramatic transformation of not only political but also symbolic space. In other post-Soviet republics, the Soviet list of martyrs was being replaced by a nationally colored pantheon, which was accompanied by symbolic recoding of the past - the same historical characters who had previously been in the status of criminals became martyrs. In Russia, such a radical option, meaning a complete rejection of the Soviet heritage, was impossible both for political and socio-cultural reasons, as a result of which a certain symbolic vacuum arose. The state almost completely distanced itself from symbolic politics, so a competition between various political and cultural actors unfolded to get vacant positions in the symbolic space. We can agree with J. Alexander, who states that the scale of social disasters does not yet create collective trauma. Trauma occurs when the situation of anomia (in the terminology of E. Durkheim) makes it impossible to maintain the former collective identity, forcing us to wonder about the conditions for the construction of a new community (Alexander 2004a: 527-528).

Interestingly, during the August Coup of 1991, three people who were killed were posthumously awarded the title Hero of the Soviet Union, but no official martyrdom was established. The monuments erected at the Vagankovo 
Cemetery became a manifestation of private, but not collective memory. In this we can see a certain parallel with the events on the Maidan in 2014, when the cult of the Heavenly Hundred, which U. Blacker analyzes in his article, arose immediately after the events and was quickly fixed at the state level (Blacker 2015: 278-279). The Russian authorities did not seize the chance to create a cult of martyrs, obviously because martyrs should consolidate in the public consciousness an important idea or key event that underlies a new identity. But for the authorities, the issue of a sharp break with Soviet identity remained problematic for political and legal reasons (membership in the United Nations Security Council).

Despite the democratic changes in the country, conservative trends are beginning to grow in the mass consciousness. One of the directions is the desire for a complete deconstruction of the Soviet past and its replacement in an idealized way with imperial Russia, which would automatically mean a complete rejection of the entire Soviet pantheon. In parallel with this, nostalgia for political and social stability gives rise to an increase in the popularity of I.V. Stalin, who begins to be perceived as a defender of the integrity of the country (Koposov 2017). These moral attitudes, despite being seemingly opposite, resonate with a large proportion of the population most affected by social and economic reforms.

The Russian Orthodox Church is trying to fill the empty symbolic niche, which in the late 1980s began to actively advocate for the rehabilitation of repressed priests. This trend is reflected in the emergence of the term "neomartyrs". Although historically this term was applied to those martyrs who were identified as saints after the fall of Constantinople (1453), in post-Soviet conditions it quickly took on a narrower meaning, marking those priests who died during the revolution or became victims of political repressions of the 1920s-1930s.

It is worth noting that for the first time representatives of the Russian Orthodox Church Abroad spoke about neomartyrs in the 1940s, and their information was based on rumors and unverified data about the circumstances of the life and martyrdom of the injured priests. In the last years of the Soviet Union, these materials were also available to the Russian Orthodox Church, which in 1989 created the Synod Commission for the Canonization of Saints, which prepared materials for the canonization of new martyrs. At the Council of Bishops in 2000, 1097 people were immediately counted among the saints. However, in most cases such a mass canonization did not rely on existing local cults and related narratives about the life path of the new martyrs, so it did not fulfill its social function. The very mass nature of the act of canonization contradicted one of the most important conditions for the effectiveness of 
martyrological thinking, namely the individuality of the fate of martyrs. That is why, as V.A. Orlovskiy notes, already in 2011 it was decided to shift the emphasis from increasing the number of martyrs to popularizing their lives among Russians (Orlovskiy 2018: 147-148).

At the same time, a large distribution - first in the Russian Orthodox Church Abroad, and then in the Russian Orthodox Church - was acquired by the Tsaras-God movement, which advocated the designation of Saint Nicholas II as a martyr. The ideological content of the doctrine is the idea that the martyrdom of the last Russian emperor became a metaphysical payment for the future restoration of Russia, and Nicholas II himself is comparable in the size of the sacrifice made to Christ. It is clear that from the point of view of the canons such a doctrine cannot be considered Orthodox, but it was in the 1990s that it became widespread not only among ordinary Russians, but also among a significant part of the priests. In the Russian Orthodox Church Abroad, Nicholas II was officially recognized as a martyr, and the public outcry led to the fact that in 2000 the Russian Orthodox Church was forced to identify him not as a saint, but as a passion bearer. Although, as already mentioned above, such canonical differences do not affect the character of the folk cult.

For the Russian Orthodox Church, the official recognition of the martyrdom of Nicholas II was, in many respects, a compromise for the reunion procedure with the Russian Orthodox Church Abroad. At the same time, even in the church itself, the attitude towards the cult of the last Russian emperor was far more ambiguous, as evidenced by the long procedure for recognizing his remains as genuine (Leeper 2001).

M. Laruelle believes that the active spread of the cult of Nicholas II should be associated with the years 2013-2014. In 2013, the anniversary of the accession to the throne of the Romanov dynasty was celebrated, and in 2014, rebels in the Donbass turned to the images of the last Russian emperor, which was caused by the personal sympathies of their leader Igor Strelkov (Laruelle 2019). In my opinion, these events rather expanded the potential for using the image of Nicholas II, but the main actors were no longer church communities, but a wider range of conservative public organizations. The church was, in a sense, hostage to the decision, which significantly limited the boundaries of the use of the image of Nicholas II, making the Russian Orthodox Church automatically responsible for observing the canonical image.

What made the last Russian emperor a convenient object for martyrological thinking? On the one hand, the relative distance in time of life from the modern Russian society, and on the other, positive associations with the Russian Empire. Nicholas II as a historical character does not cause polar emotions; in addition, 
the use of his image allows him to fulfill an important moral function - removing personal responsibility from modern Russians and shifting it to the direct culprits of the emperor's murder.

One of the most prominent representatives of the Tsar-as-God doctrine is monk Sergius (Romanov), who actively advocates the expanding of the cult of Nicholas II, and in his interpretation the martyrdom of Nicholas II acquires the features of a moral imperative addressed to the modern Russian government. In particular, we are talking about public repentance for the crimes of the Soviet period and the refusal of continuity with the Soviet Union. Thus, the cult of Nicholas II, which, it would seem, does not contradict the official state ideology, becomes a catalyst for public dissatisfaction with the conservative layers of the Russian society that could not overcome the collective trauma of the collapse of the Soviet empire.

But no less important aspect of the use of the martyrdom image of Nicholas II is the dynamics of intra-church conflicts and divisions. In the modern Russian Orthodox Church, two wings are clearly distinguished - conservative and liberal, each of which not only fights for the drift of the church in one direction or another, but also actively participates in the distribution of posts and power. It is important to understand that the policy of Patriarch Kirill, aimed at achieving the synthesis of the church and the state (despite the forced nature of such aspirations), is criticized from liberal and conservative positions. But while the liberal part of the church contrasts the church with the idea of sobriety and complicity, then in the hands of conservatives the image of martyr Nicholas II becomes a symbol of 'real' power (as opposed to the Soviet origin of the modern Russian elite).

The inability to build a collective identity without the Soviet past makes today's Russian authorities not expand the set of historical images, but again turn to the symbolic resource of World War II. Also, we are talking about the re-revival of the Soviet martyrdom cult.

U. Blacker believes that the emergence of a new martyrological thinking should not be considered in the context of addressing the past, but as related to the memory wars that unfolded in Eastern Europe in connection with the rethinking of the results of World War II (Blacker 2015: 258-260). The collapse of the communist camp led to the emergence of the concept of double occupation, as most countries in Eastern Europe began to interpret their history of recent decades as a consistent struggle first against Nazism, and then against communism. In this context, the consolidation of conservative trends in postSoviet Russia should be considered not only as a phenomenon of historical nostalgia, but also as an important element of political struggle. The emphasized attention to the figures of martyrs of the Soviet era becomes a way to oppose 
Eastern European revisionism, not just the 'true' memory of the war, and also to legitimize the right to possess this memory.

In the early 1990s, a general trend was the debunking of the cults themselves, or the voicing of those historical details that were classified in the Soviet period. For example, the materials of the verification by the public prosecutor's office of journalistic reports about the feat of the Panfilov Division's Twenty-Eight Guardsmen were published, as a result of which, firstly, the artificial nature of the list of dead participants in the battle was clarified, and secondly, the presence of the still living participants in the official martyrology. An important circumstance was the fact that one of the participants in the canonical list, Ivan Dobrobabin, not only remained alive in the famous battle, but was captured, began to cooperate with German troops and became a policeman. After the war, the circumstances of his betrayal became known to state security bodies, which led to the deprivation of his title of Hero of the Soviet Union, but his name was not removed from the monument. In the post-Soviet years all attempts made by Dobrobabin himself to achieve rehabilitation and to get back the awards were unsuccessful.

Although in the 1990s discussions regarding the assessment of the authenticity of the Soviet 'martyrs' were still allowed, with the strengthening of conservative trends the very question of reassessing the past began to seem unacceptable. When in 2016 Sergey Mironenko, the director of the State Archive of the Russian Federation, called the feat of the Panfilovtsy a myth, the public reaction of the Minister of Culture, Vladimir Medinsky, turned out to be very tough. Mironenko was dismissed from the post of director of the archive, retaining, however, the position of scientific director of this organization. A symbolic response to the attempts of researchers to revise some of the stamps that developed during the war and were refuted even by the Soviet prosecutor was the film Panfilov's $28 \mathrm{Men}$, released in the same year, in which the legendary plot was completely reproduced.

An important feature affecting the formation and support by the state of martyrdom cults is the risk of a situation in which the state itself is one of the culprits of trauma. Related to this is the cautious and even negative attitude of the Russian authorities towards those unofficial cults of martyrs that are developing already in the post-Soviet era and are associated with the recent past.

This statement can be illustrated by various strategies for preserving the memory of events in Beslan. In September 2004, Chechen terrorists seized a school and held it for three days. During the assault on the school, a large number of hostages, including children, died. Almost immediately after the tragic events, alternative versions of what had happened arose. The official version claimed that the cause of the deaths of the hostages was the bombing 
of terrorists, so the operation is the embodiment of the heroism of the special services. The unofficial version voiced by the public organization Mothers of Beslan was that most of the hostages died during the assault from artillery shells, so the dead children are victims not only of the actions of terrorists, but also of the incompetence of the armed forces. The Russian authorities quickly tried to neutralize negative connotations by establishing a Day of Solidarity against Terrorism in 2005, as well as erecting a number of monuments memorializing not only the dead hostages, but also the fighters of the special services who died during the assault. The emphasized heroization of their actions was designed to publicly dispel doubts about possible guilt, and the very name of the memorable date was to unite all the participants in the tragic events in Beslan.

At the same time, the public organization Mothers of Beslan, having developed a ritual of preserving the memory of them, emphasized not heroism, but the martyrdom of the dead children. Every year on September 1, children's toys are brought to the school and candles are lit in memory of the dead, and the transfer of emphasis from heroism to martyrdom becomes the basis for a reaction from the authorities. For example, in 2016, several representatives of this organization were detained for trying to organize an unauthorized memory action. It can be noted that the spontaneous martyrdom cult is considered as potentially dangerous to the symbolic appearance of the state, which forces the shift of the emphasis from the specific images of the dead to the abstract fight against terrorism.

In conclusion, martyrological thinking is a mechanism for maintaining historical memory and collective identity. Because of their religious nature, such thinking has a certain ambivalence, often acting as a mechanism for the occurrence of collective injuries. In the context of the secularization of the society and the formation of civil religion, the phenomenon of martyrdom becomes an important element of socialist or nationalist ideologies. In the Soviet Union period, two stages of the creation of martyrdom cults can be distinguished - the Civil War and the Great Patriotic War. Compared to the previous tradition, the ideological content of cults changed (faith in communism and the defense of the motherland instead of the Christian faith), as did the social status of martyrs (working or peasant origin instead of dynastic affiliation).

While in Soviet society martyrdom cults were combined with heroic discourse, acting as an additional moral justification, then in post-Soviet society they become a mechanism of traumatization. On the one hand, there is an artificial preservation of those martyrdom cults that were inscribed in the history of the Great Patriotic War in the Soviet period, and the actualization of these cults is superimposed on the strengthening of foreign policy isolation. On the other 
hand, the spontaneous folding of the martyrdom of Nicholas II or the children killed in the terrorist act in Beslan creates grounds for legitimizing protest sentiments, so their use in the symbolic policy of the state is almost impossible.

\section{ACKNOWLEDGEMENTS}

The study was funded by the Russian Science Foundation (RSF), project number 19-18-00421.

\section{REFERENCES}

Alexander, Jeffrey C. 2004a. Cultural Pragmatics: Social Performance between Ritual and Strategy. Sociological Theory, Vol. 22, No. 4, pp. 527-573. http://dx.doi. org/10.1111/j.0735-2751.2004.00233.x.

Alexander, Jeffrey C. 2004b. Toward a Theory of Cultural Trauma. In: Jeffrey C. Alexander \& Ron Eyerman \& Bernard Giesen \& Neil J. Smelser \& Piotr Sztompka (eds.) Cultural Trauma and Collective Identity. Berkeley \& Los Angeles \& London: University of California Press, pp. 1-30.

Bélanger, Jocelyn \& Caouette, Julie \& Sharvit, Keren \& Dugas, Michelle 2014. The Psychology of Martyrdom: Making the Ultimate Sacrifice in the Name of a Cause. Journal of Personality \& Social Psychology, Vol. 107, No. 3, pp. 494-515. http:// dx.doi.org/10.1037/a0036855.

Blacker, Uilleam 2015. Martyrdom, Spectacle, and Public Space: Ukraine's National Martyrology from Shevchenko to the Maidan. Journal of Soviet and Post-Soviet Politics and Society, Vol. 1, No. 2, pp. 257-292. Available at https://www.academia. edu/26399982/, last accessed on 7 April 2021.

Blacker, Uilleam 2019. Memory, the City and the Legacy of World War II in East Central Europe. New York: Routledge.

Bourdieu, Pierre 1986. The Forms of Capital. In: John Richardson (ed.) Handbook of Theory and Research for the Sociology of Education. Westport, CT: Greenwood Press, pp. 241-258.

Durkheim, Emile 1995 [1912]. The Elementary Forms of Religious Life. Transl. by Karen E. Fields. New York: The Free Press. Available at https://monoskop.org/images/a/ a2/Durkheim_Emile_The_Elementary_Forms_of_Religious_life_1995.pdf, last accessed on 7 April 2021.

Frend, William H. C. 2008 [1965]. Martyrdom and Persecution in the Early Church: A Study of a Conflict from the Maccabees to Donatus. Cambridge: James Clarke Company.

Girard, René 1977. Violence and the Sacred. Transl. by Patrick Gregory. Baltimore: Johns Hopkins University Press. 
Gölz, Olmo 2019. The Imaginary Field of the Heroic: On the Contention between Heroes, Martyrs, Victims and Villains in Collective Memory. In: Nicole Falkenhayner \& Sebastian Meurer \& Tobias Schlechtriemen (eds.) Analyzing Processes of Heroization: Theories, Methods, Histories. Special Issue 5: helden. heroes. héros. E-Journal zu Kulturen des Heroischen, pp. 27-38. Available at https://freidok. uni-freiburg.de/data/151762, last accessed on 7 April 2021.

Halbwachs, Maurice 1941. La Topographie légendaire des Évangiles en Terre Sainte; étude de mémoire collective. Paris: Presses Univ. de France. Available at https:// www.ssoar.info/ssoar/handle/document/50461, last accessed on 7 April 2021.

Koposov, Nikolay E. 2017. Memory Laws, Memory Wars: The Politics of the Past in Europe and Russia. Cambridge: Cambridge University Press.

Laruelle, Marlene 2019. Commemorating 1917 in Russia: Ambivalent State History Policy and the Church's Conquest of the History Market. Europe-Asia Studies, Vol. 71, No. 2, pp. 249-267. http://dx.doi.org/10.1080/09668136.2018.1552922.

Leeper, Mark 2001. The Schism of the Russian Orthodox Church and the Canonization of Nicholas II and the Royal Family. Diss. (PhD Thesis). University of Texas.

Mazour, Anatole G. 1937. The First Russian Revolution, 1825: The Decembrist Movement, Its Origins, Development, and Significance. Stanford: Stanford University Press.

Olivola, Christopher Y. \& Shafir, Eldar 2013. The Martyrdom Effect: When Pain and Effort Increase Prosocial Contributions. Journal of Behavioral Decision Making, Vol. 26, No. 1, pp. 91-105. http://dx.doi.org/10.1002/bdm.767.

Orlovskiy, V.A. (archimandrite Damaskin) 2018. Canonization of New Martyrs in the Russian Orthodox Church. Tractus Aevorum, Vol. 5, No. 1, pp. 135-164. http:// dx.doi.org/10.18413/2312-3044-2018-5-1-135-164.

Price, Simon R.F. 1984. Rituals and Power: The Roman Imperial Cult in Asia Minor. Cambridge: Cambridge University Press.

Daniil Anikin is Head of the Laboratory of Historical and Political Culture, Associate Professor of the Department of History and Theory of Politics at Moscow State University, and researcher at Tomsk State University. The sphere of scientific interests includes the politics of memory, civil religion, and the reflection of historical subjects in mass culture.

dandee@list.ru 